\title{
АКЦЕССОРНЫЕ МИНЕРАЛЫ КАНЕВСКО-БУЧАКСКИХ ОТЛОЖЕНИЙ В СВОДОВОЙ ЧАСТИ ВОРОНЕЖСКОЙ АНТЕКЛИЗЫ НА ТЕРРИТОРИИ ЛИСТА М-37-ХІ (БОБРОВ)
}

\author{
Е. Ю. Никитин \\ Воронежский государственный университет
}

Поступила в редакцию 20 августа 2018 г.

\begin{abstract}
Аннотация: рассмотрены акиессорные минераль каневско-бучакских отложений в четырех опорных разрезах на территории листа М-37-ХІ (Воронежская область). Эти разрезы сложены песками мелкозернистыми, преимущественно, сортированными, за исключением разреза т.н. 191, где они разнозернистые. Легкая фракиия песков состоит из зерен кварияа, глауконита (от первых до 15 \%), полевых шпатов (до 9\%) и глинистой составляющей, в среднем, от 0,5 до $3 \%$, реже до $10 \%$. Содержание тяжелой фракиии от первых долей до 0,5\%, она представлена лейкоксен-цииронильменитовой ассочиаџией с примесью других минералов. Полученные результать гранулярного и минералого-петрографического изучения каневско-бучакских песков показали, что формирование песков происходило в мелководно-морском бассейне с неоднородной морфологией дна в условиях различных гидродинамических режимов. Низкое содержание и состав тяжелой фракции не позволяет положительно оценить перспективы нахождения на рассматриваемой площади промышленных россыпей тяжелых минералов.

Ключевые слова: палеоген, каневско-бучакские отложения, акиессорные минералы, гранулометрический анализ, тяжелая фракция.

\section{ACCESSORY MINERALS OF KANEVSKO-BUCHAKSKY DEPOSITS IN THE ARCHED PART OF VORONEZH ANTECLINE ON THE TERRITORY OF SHEET M-37-XI (BOBROV)}

Annotation: accessory minerals of Kanevsko-Buchaksky deposits in four reference sections on the territory of M-37-XI sheet (Voronezh region) are considered. These sections are composed of sands of finegrained, predominantly sorted, with the exception of the so-called cut. 191, where they are heterogeneous. The light fraction of sands consists of grains of quartz, glauconite from the first to $15 \%$, feldspars up to $9 \%$ and clay constituents, on average, from 0,5 to 3, less often up to $10 \%$. The heavy fraction from the first fraction to $0,5 \%$, and its lycoxene-zircon-ilmenite association with an admixture of other minerals. The results of granulometric and mineralogical-petrographic study of Kanev-Buchak sands showed that the formation of sands occurred in a shallow-water basin with a heterogeneous bottom morphology under conditions of various hydrodynamic regimes. The low content and composition of the heavy fraction does not allow a positive assessment of prospects for reasonable areas.
\end{abstract}

Key words: Paleogene, Kanev-Buchak deposits, accessory minerals, granulometric analysis, heavy fraction.

Акцессории тяжелой фракции каневско-бучакских отложений палеогена Воронежской антеклизы рассмотрены в ряде работ [1-6], но на рассматриваемой площади данные по составу тяжелых минералов этих образований отсутствуют. Этот пробел был восполнен автором в результате начавшейся с 2017 года государственной геологической съёмки ГДП-200 листа М-37XI (Бобров). В её процессе автору были предоставлены фондовые материалы, а также 19 образцов каневско-бучакских песков из четырех разрезов, (точки наблюдения $162,168,181,191$, рис. 1,2$)$. Пески изучены с помощью гранулярных, минералого-петрографических и микрозондовых анализов.
Написание настоящей статьи было бы невозможным без активной помощи сотрудников геологовсъёмщиков А. В. Черешинского, А. В. Крайнова, А. В. Милаша. Они любезно предоставили образцы для исследований и помогали советами в процессе выполнения работы. При интерпретации аналитических данных автор активно пользовался консультациями сотрудников геологического факультета, доктора геол.-мин. наук А. Д. Савко, кандидатов геол.-мин. наук Д. А. Дмитриева Д. А. Иванова, И. П. Лебедева. Их всех автор искренне благодарит.

Территория листа М-37-XI (Бобров) относится к району трёхъярусного геологического строения. 


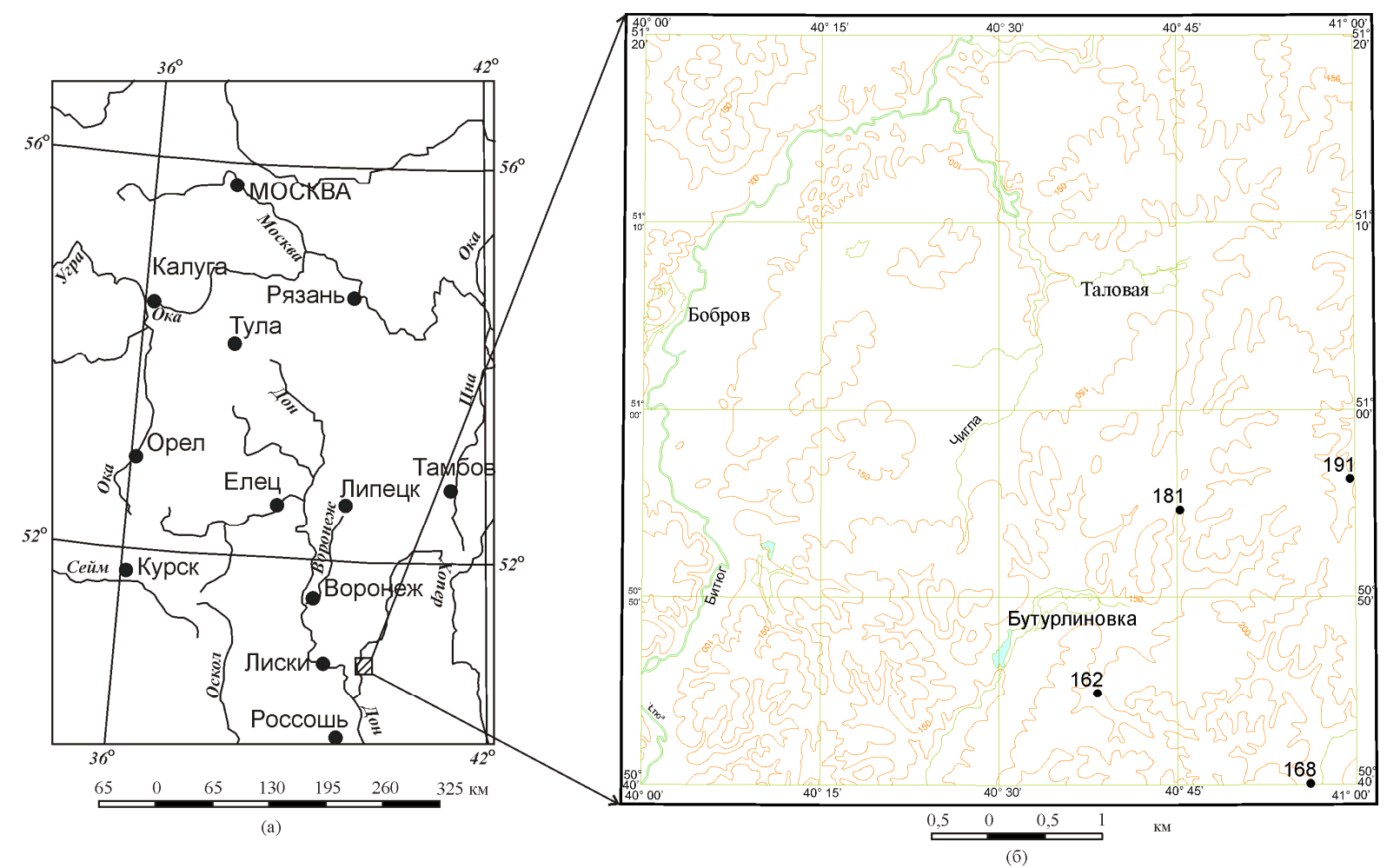

Puc. 1. Схема расположения изученных разрезов каневско-бучакских отложений: $a$ - положения листа М-37-ХІ (Бобров) на карте РФ, $\sigma$ - расположение изученных разрезов на площади листа М-37-ХІ (Бобров).

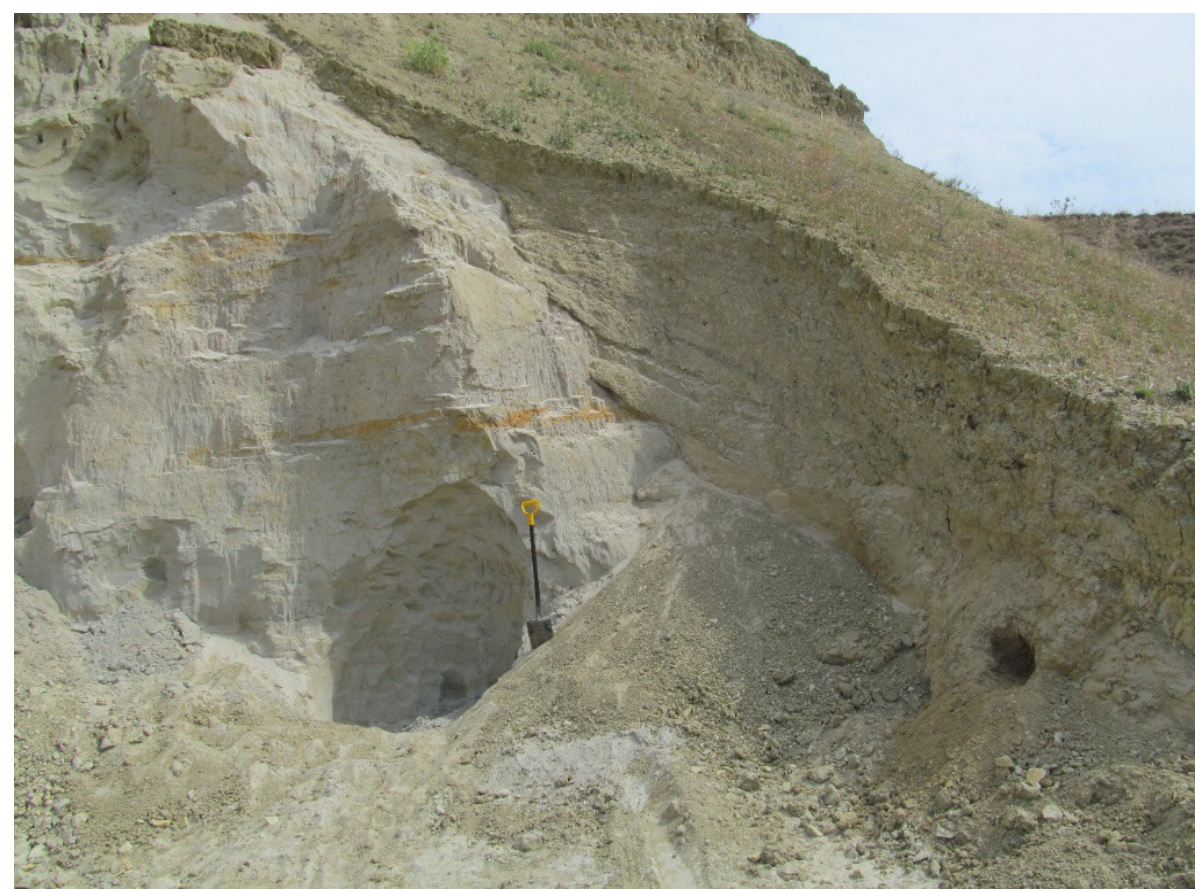

Puс. 2. Фото точки наблюдения 191.

Нижний ярус представлен сложно дислоцированными и метаморфизованными породами архея и нижнего протерозоя, прорванными многочисленными интрузиями различного состава. Второй ярус - это залегающие субгоризонтально осадочные породы девона, мела и палеогена общей мощностью до 250 м. Третий ярус - континентальные неогеновые и четвер- тичные отложения, развитые почти повсеместно и перекрывающие отложения других генетических типов, мощностью от нескольких метров до $30-40$ м. Эрозионной сетью довольно полно вскрываются породы четвертичной, неогеновой, палеогеновой и меловой систем. В полевых условиях расчленение каневской и бучакской свит эоцена крайне затруднено, 
поэтому они описываются вместе.

В литологическом отношении рассматриваемые отложения не отличаются большим разнообразием и представлены алеврито-песчаными породами с примесью глинистой составляющей от долей до 10-15\%. Её количество увеличивается с уменьшением размерности песков. По минеральному составу пески олигомиктовые, содержание кварца в них обычно выше 80 и может достигать 97 \%. Выход тяжелой фракции составляет от первых долей до 0,5 процента.

Каневская свита развита на юге и юго-востоке листа, с размывом залегает на образованиях сумской свиты или породах верхнего мела. Низы разреза чаще сложены светлыми кварцевыми песками с примесью глауконита, слабослюдистыми, с прослоями песчаников. Выше залегают зеленовато-серые алевритистые глины и алевриты, местами слоистые, с зернами глауконита. В основании разреза отмечаются следы перерыва и галечники фосфоритов и кремней. Мощность свиты до $11 \mathrm{M}$.

Бучакская свита развита шире каневской, залегает на ней со следами размыва, представлена преимущественно песчаными породами. Пески серые, зеленовато-серые, светло-серые до белых, кварцевые с примесью глауконита, слюдистые от мелко- до средне- и крупнозернистые, с прослоями и линзами сливных песчаников, реже - глин, в основании отмечается галька фосфоритов и черных кремней. В ряде разрезов внутри песчаной толщи наблюдается хорошо окатанная галька фосфоритов и кремней. Мощность бучакской свиты до 14 м.

Основным породообразующим минералом каневско-бучакских отложений является кварц. Величина его зерен колеблется от пылеватой до гравийной, но обычен он в мелко- и среднезернистых фракциях. Зерна этого минерала округлой формы, реже угловато-окатанные, иногда с эпигенетическими пленками гидроокислов железа, содержат глинистые примазки.

Глауконит встречается в количествах от первых до $14 \%$, обогащая отдельные прослои мощностью до 1,5 м, которые в таких случаях приобретают зеленовато-серую окраску. Встречен в виде мелких округлых зернах зеленого цвета, тяготеет к тонкозернистым разностям песков. Отмечаются слои песков, практически не содержащие глауконит. Третьим, постоянно присутствующим минералом, является калиевый полевой шпат, содержания которого колеблются в пределах первых десяти процентов. Встречается в угловато-окатанных зернах сероваторозоватой окраски, тяготеет к алевритистым разностям песков. Мусковит (иллит) в виде чешуек неправильной имеется практически во всех пробах, но заметные количества его (первые проценты) встречаются в глинистых алевритах и тонкозернистых песках. Опал и халцедон отмечены в отдельных пробах, где их содержание не превышает 1-2 \%.

В тяжелой фракции из непрозрачных минералов определены ильменит, лейкоксен, гидроокислы железа. Прозрачные минералы представлены цирко- ном, рутилом, дистеном, ставролитом, турмалином, гранатом, силлиманитом, шпинелью, изредка амфиболом.

Ильменит является одним из наиболее распространённых минералов непрозрачной составляющей тяжелой фракции исследованных отложений. Обычно он имеет размерность зерен $<0,4$ мм, основной концентрирующей является фракция 0,2-0,05 мм [5]. Цвет минерала меняется от темно-чёрного, буроваточёрного до бурого, светло-коричневого. Блеск полуметаллический. Спайность отсутствует. Излом неровный или раковистый. Содержания ильменита колеблются в широких пределах, но в среднем близки к 50 $\%$ от всего ее количества (рис. 3.)

Лейкоксен присутствует во всех пробах (рис. 3). Обычно его зерна округлой формы и представлены скрытокристаллическими агрегатами. Поверхность у них гладкая, реже шероховатая. Цвет минерала по мере его преобразования по ильмениту варьирует от белесовато-жёлтого до буровато-коричневого с различными оттенками, блеск фарфоровидный, жирный или матовый.

Гидроксиды и оксиды железа являются типичными образованиями исследуемых образований. В геологической литературе до сих пор встречается устарелая терминология, обозначающая данные образования термином окислы. На самом деле, ведущие минералы данной группы представлены гётитом, гематитом, лепидокрокитом и их разновидностями, насыщенными водой [5].

Циркон - наиболее распространенный прозрачный минерал рассматриваемых отложений. В целом для изученных пород все цирконы объединяются в основные типы [7]: «цирконовый», «гиацинтовый», «копьевидный», «изометричный», «дипирамидальный» (конвертоподобный), «призматический» (плоскопризматический). Окраска минерала весьма разнообразна: бледная винно-желтая, розовая, молочнобелая, светло-коричневая, бурая, также циркон часто бесцветен. Блеск сильный алмазный. Спайность неотчетливая, излом неровный или раковистый.

Рутил образует значительные концентрации. Окраска рутила разнообразна: красно-бурая, коричнево-красная, бурая, буровато-желтая, оранжево-желтая, блеск алмазный. Спайность средняя, несовершенная.

Гранат в исследованных отложениях характеризуется значительным морфологическим разнообразием. Редко он представлен в виде бледно-розовых идиоморфных кристаллов размером около 0,2 мм, на единичных из них развиты грани ромбододекаэдра [4]. Чаще встречаются зерна от неправильно-угловатой до угловато-окатанной, полуокатанной и хорошо окатанной форм. Преобладает альмандин бледнорозового цвета. Блеск стеклянный, на гладких гранях кристаллов приближается к алмазовидному, просвечивает. Под микроскопом прозрачен, изотропен. Содержание граната (альмандина) колеблется в пределах 2-9 \% от общего количества тяжелой фракции в \% (рис. 3). 

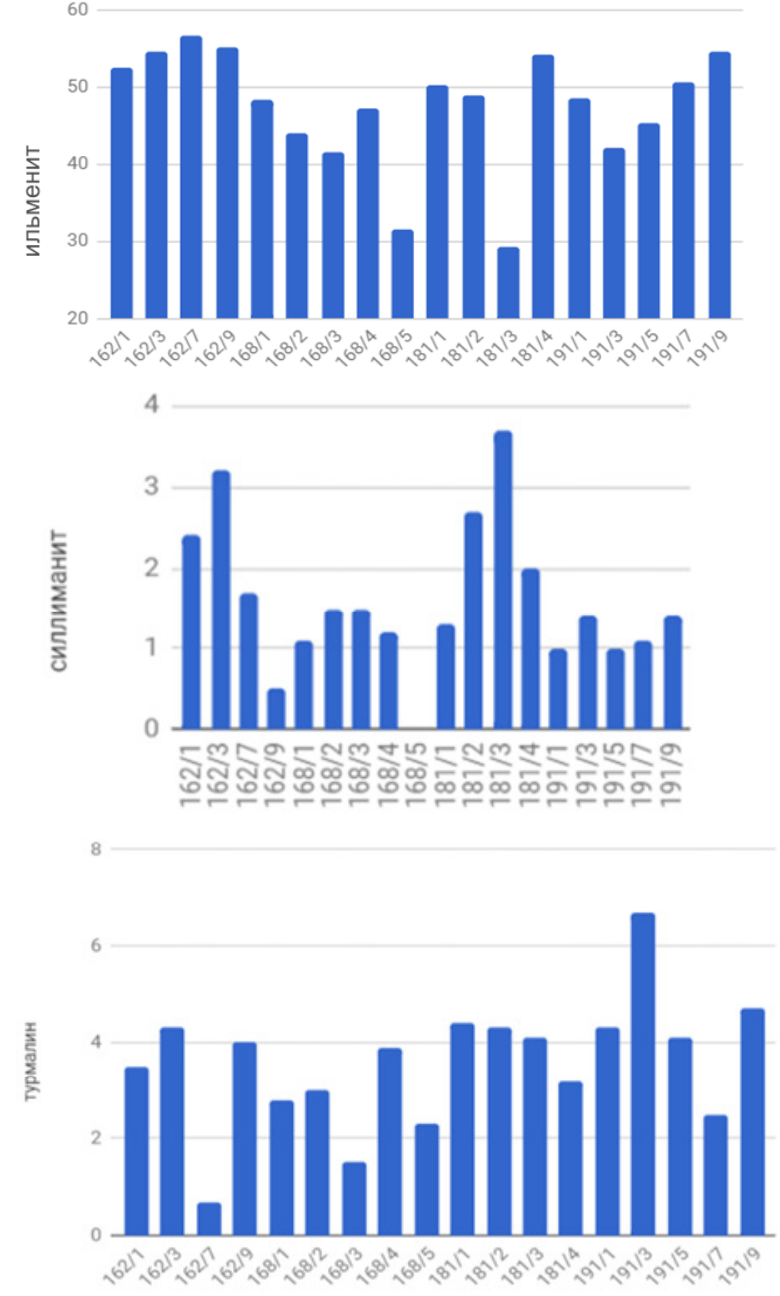

20
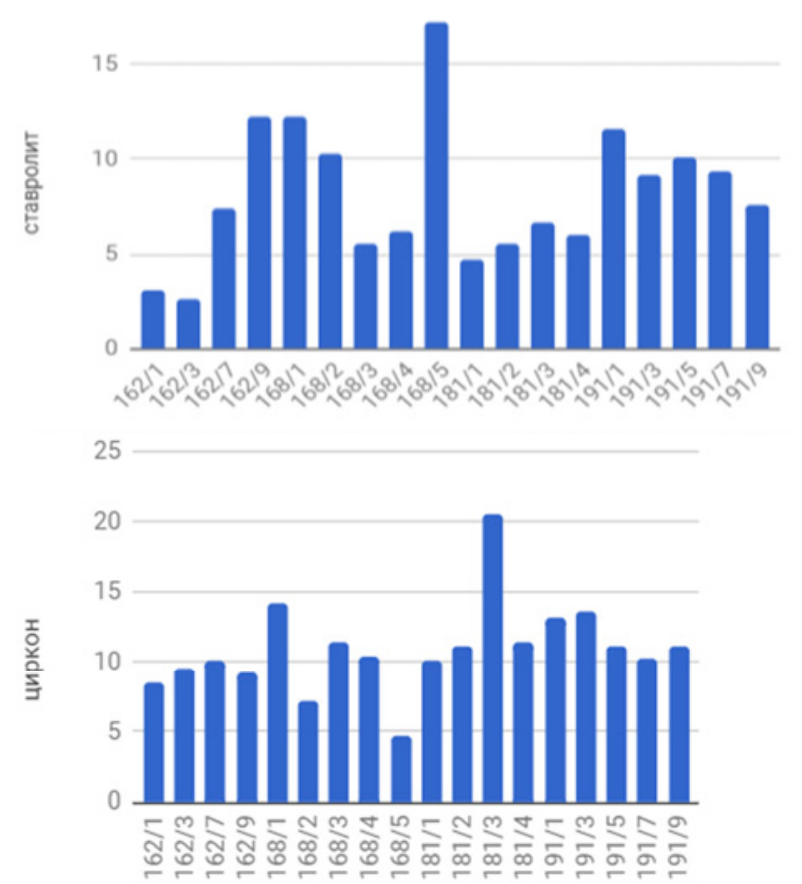
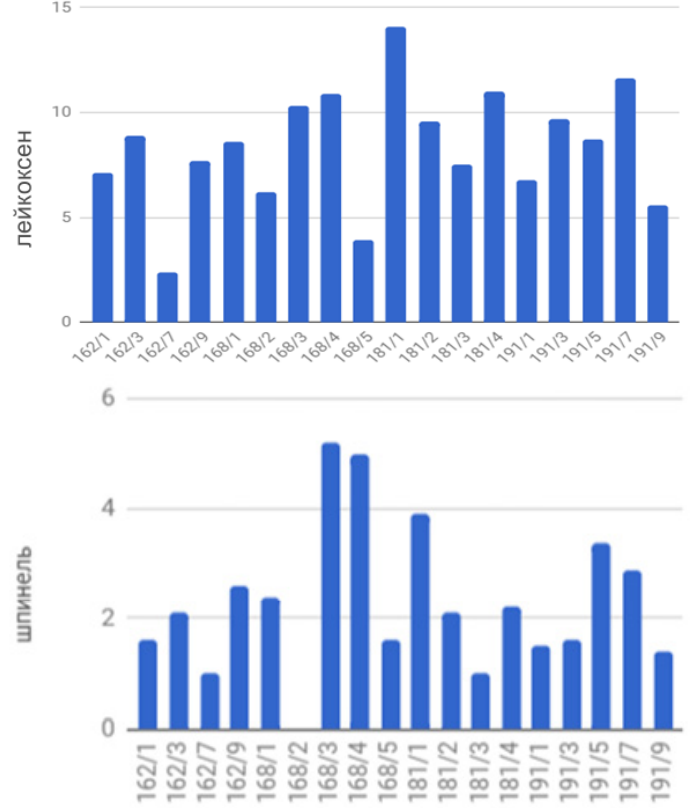

20
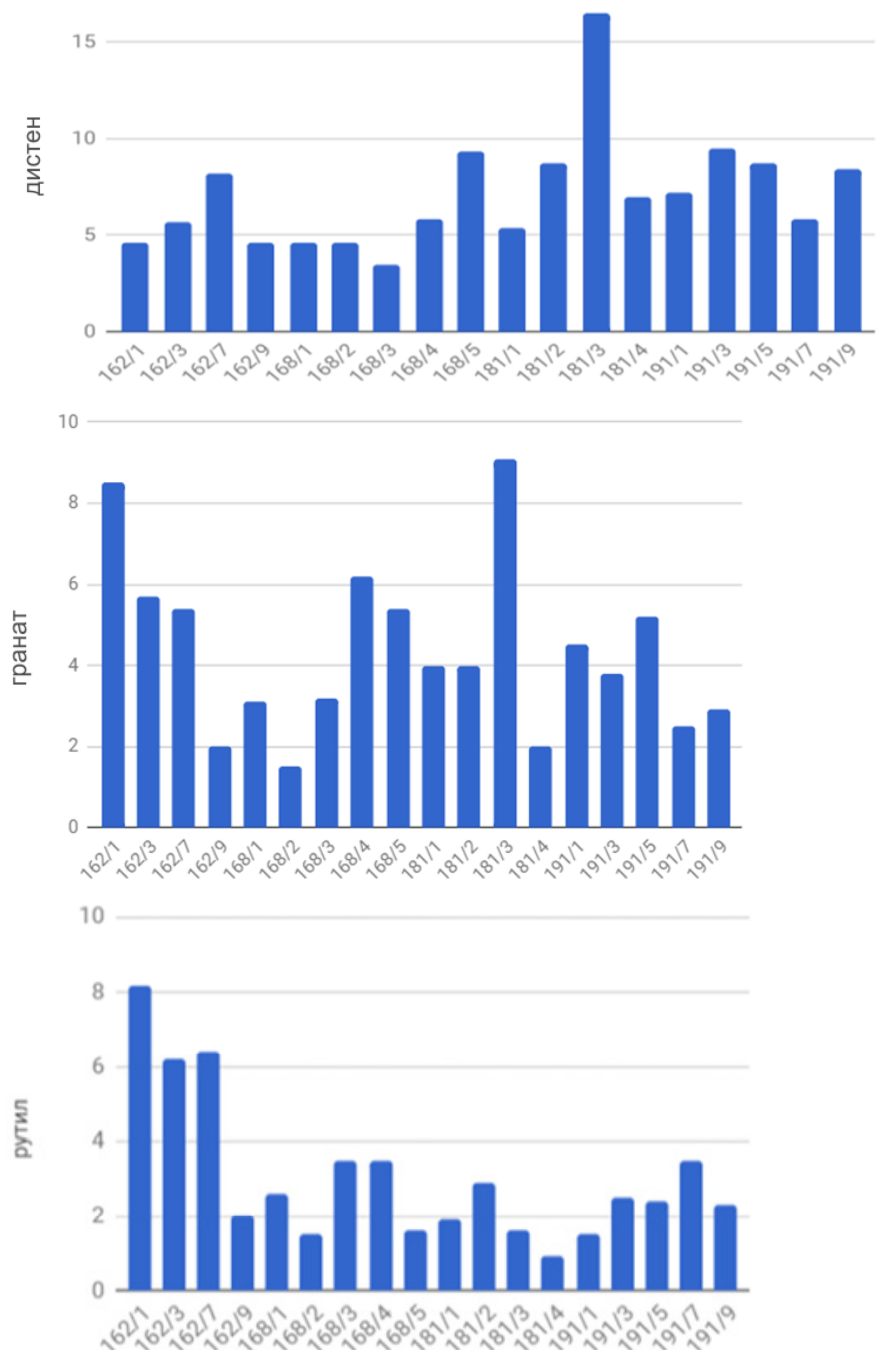

Puc. 3. Графики содержаний акцессориев (\%) от общего количества минералов тяжелой фракции по изученным пробам. 
Ставролит довольно распространенный минерал и наблюдается чаще всего в виде обломков неправильной формы с зазубренными гранями, а также в форме угловато-окатанных, реже окатанных зёрен. Минерал характеризуется неровной мелко ямчатой или шагреневой поверхностью, цвет его желтый с различными по насыщенности оттенками, вплоть до буровато-коричневого в наиболее крупных обломках, практически не просвечивающих. Спайность заметная, излом раковистый. Под микроскопом прозрачен и окрашен в желтые и коричневые тона. Весьма характерен плеохроизм от бесцветного до желтокоричневого цвета. Содержание зерен ставролита в от 2 до $17 \%$ (рис. 3 ).

Дистен (кианит) чаще всего наблюдается в виде удлинённых, нередко прямоугольных зёрен, а также обломочных частиц, с сохранением морфологических особенностей (дощатая или удлинённо-пластинчатая форма). Цвет его белый, голубоватый, сероватый изза включений темноцветных минералов, желтоватый за счет окрашивания по трещинам спайности оксидами железа. В большинстве случаев он обладает очень хорошей прозрачностью (особенно в бесцветных разновидностях). Блеск стеклянный, спайность совершенная, параллельно ей очень часто наблюдается две системы. Содержание минерала в среднем порядка 7 $\%$ (рис. 3).

Силлиманит представлен шестоватыми длиннопризматическими (до игольчатых) кристаллами, несущими штриховку по удлинению зерен. Повышенные содержания всех разновидностей силлиманита (рис. 3), как и дистена, обычно концентрируются в размерной фракции $0,1-0,25$ мм.
Турмалин имеет призматический облик. Конечные грани на кристаллах слабо выражены. Цвет минерала темно-коричневый, коричнево-бурый, черно-бурый, блеск стеклянный, излом раковистый, спайность не выражена. Количество минерала колеблется от 2 до 7 $\%$ (рис. 3).

Шпинель (первые проценты, рис. 3) представлена в виде идиоморфных и субидиоморфных размером от 0,1 до 0,4 мм октаэдрических кристаллов, осложненных мелкими вершинными гранями со сглаженными углами и ровными, гладкими, не скульптурированными основными гранями, реже в виде обломков или неправильных зёрен. Кристаллы этого минерала очень разнообразны по окраске, чаше встречаются голубоватая, зеленоватая и бесцветная разновидности. Блеск шпинели стеклянный, излом мелкораковинный. Она прозрачна в различной степени, отдельные зёрна водяно-прозрачные (рис. 4).

Aмфиболь, присутствующие, как правило, в незначительных количествах, представлены шестоватыми, иногда удлиненными обломками кристаллов и неправильными угловатыми зернами, часто имеющими неровные зубчатые, ступенчатые очертания. Цвет амфиболов светло-зеленый, грязно-зеленый, голубовато-зеленый, а также темно-зеленый, темно-зеленовато-бурый до черного (рис. 4). Амфиболы в большом количестве встречаются в единственном образце 168/2, до $10 \%$, имеют шестоватый облик, плеохроизм от желтого до зеленого, угол погасания $19^{\circ}$. Данные микрозондовых анализов (табл.) подтверждают отнесение установленных микроскопическим изучением минералов к амфиболам.
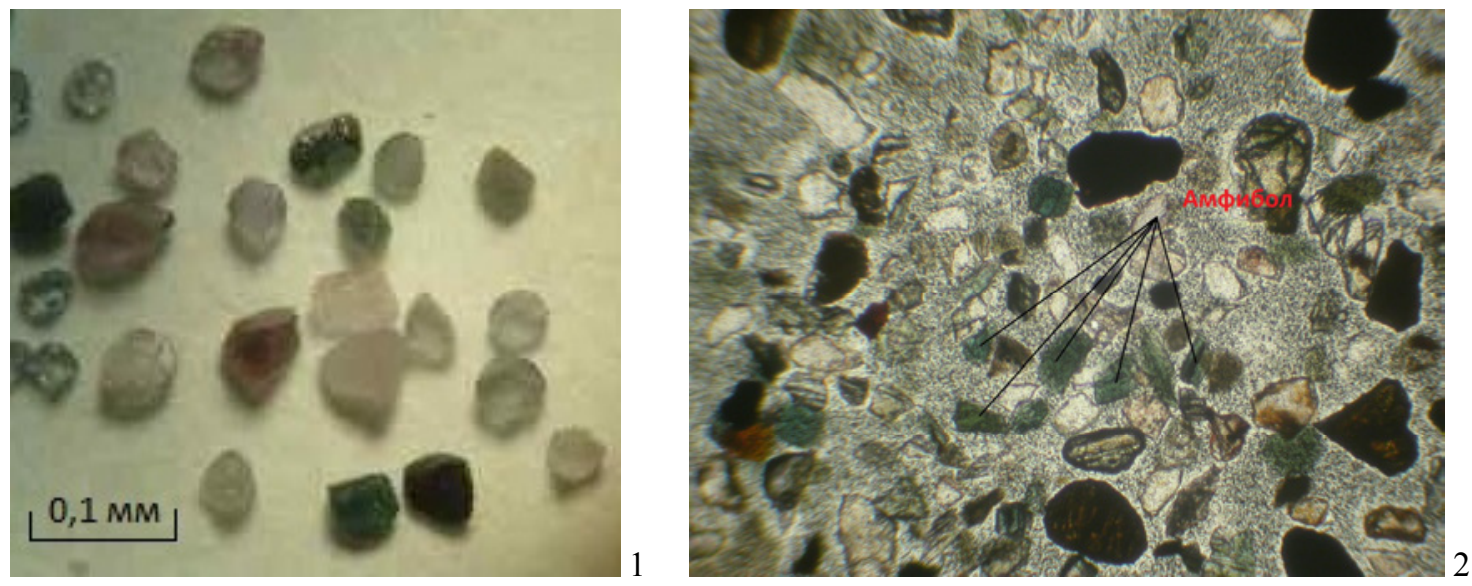

Puc. 4. Акцессорные минералы под бинокуляром: 1 - шпинель, 2 - амфибол.

Таблица

Состав амфибола по данным микрозондового анализа, проба 168/2.

Энергодисперсионный спектрометр OXFORD INCA Energy 250, (аналитик-к.г.-м.н. Н. С. Базиков)

\begin{tabular}{|c|c|c|c|c|c|c|c|}
\hline \multirow{2}{*}{ Фракция } & \multicolumn{7}{|c|}{ Содержание оксидов, \% } \\
\cline { 2 - 8 } & $\mathrm{SiO}_{2}$ & $\mathrm{FeO}$ & $\mathrm{Al}_{2} \mathrm{O}_{3}$ & $\mathrm{CaO}$ & $\mathrm{MgO}$ & $\mathrm{Na}_{2} \mathrm{O}$ & $\mathrm{MnO}$ \\
\hline $0,1-0,25 \mathrm{мм}$ & 46,5 & 18,59 & 12,59 & 11,67 & 9,66 & 1,56 & 0,53 \\
\hline & & & & & & & \\
\hline Менее 0,1 мм & 46,94 & 19,21 & 11,12 & 12,09 & 9,64 & 1,24 & 0,52 \\
\hline
\end{tabular}




\section{Выводы}

Минералого-петрографическое изучение тяжелой фракции каневско-бучакских отложений показало, что они представлены устойчивой лейкоксен-цирконильменитовой ассоциацией с примесью других минералов. Легкая фракция сложена преимущественно терригенным кварцем, свидетельствующем о «зрелости» рассматриваемых образований. Они сформировались за счет размыва нижележащих осадочных толщ, которые служили промежуточными коллекторами, охарактеризованными в серии работ ряда авторов по отложениям разного возраста [7-15]. Неясным остается появление заметного количества нехарактерного для «зрелых» пород амфиболов, не отмеченного другими авторами.

Сравнение ассоциаций акцессорных минералов, изученных автором с таковым на остальной площади антеклизы для каневско-бучакских образований по данным работ [3, 4] показало сходство их составов, представленных преимущественно устойчивыми минералами. Меняется только их процентное соотношение, что зависит от состава источников сноса, размерности песчаных фракций, фациальных обстановок, удаленности от береговой линии сформированных отложений.

Низкое содержание, состав тяжелой фракции и распределение полезных компонентов не позволяют положительно оценить перспективность нахождения на рассматриваемой площади промышленных россыпей тяжелых минералов.

\section{ЛИТЕРАТУРА}

1. Семенов, В. П. Палеоген Воронежской антеклизы / В. П. Семенов // Воронеж, 1965 - 278 c.

2. Бартенев, В. К. Литология, фации и полезные ископаемые палеогена ЦЧЭР / В. К. Бартенев А. Д. Савко // Тр. науч.-исслед. ин-та геологии Воронеж. ун-та. - Вып.7. Воронеж, 2001. - $146 \mathrm{c}$.

3. Бартенев, В. К. Сравнительный минералогический анализ минералов тяжелой фракции песчаных пород палеогена и мела на юго-востоке Воронежской антеклизы (М-37-XII) / В. К. Бартенев, А. Е. Звонарев // Проблемы литологии, ми- нералогии и стратиграфии осадочных образований Воронежской антеклизы. - Тр. науч.-исслед. ин-та геологии Воронеж. ун-та. - Вып.11. - Воронеж, 2002. - С. 73-76.

4. Звонарев, А. Е. Акцессорные минералы меловых и палеогеновых отложений Воронежской антеклизы/ А. Е. Звонарев, А. Д. Савко // Тр. науч.-исслед. ин-та геологии Воронеж. ун-та. - Вып. 29. - Воронеж, 2005 - 114 с.

5. Савко, А. Д. Основные факторы формирования титанциркониевых россыпей / А. Д. Савко, В. И. Беляев, В. К. Бартенев // Сов.геология. - 1992. - № 3. - С. 21-28.

6. Титан-циркониевые россыпи Центрально-Черноземного района / А. Д. Савко [и др.] // Воронеж : Изд-во Воронеж.унта, $1995 .-148 \mathrm{c}$.

7. Кухаренко, А. А. Минералогия россыпей / А. А. Кухаренко // Под ред. В. Б. Татарского. - М : Госгеолтехиздат, 1961. $-318 \mathrm{c}$.

8. Хожаинов, Н. П. Литология терригенных толщ палеозоя и мезозоя и проблемы их рудоносности / Н. П. Хожаинов // Дисс. д-ра геол.-мин. наук. - Воронеж, 1970. - 662 с.

10. Жуковский, А. А. Вещественный состав и условия формирования терригенных отложений девона Воронежской антеклизы и прилегающих районов / А. А. Жуковский. // Автореф. дисс. канд. геол.-мин. наук. - Воронеж, 1974. - 24 с.

11. Окороков, B. А. Литология фаменских отложений Воронежской антеклизы / В. А. Окороков, А. Д. Савко // Воронеж : Воронежский гос. ун-т, 1998. - 124 с.

12. Савко, А. Д. Литология и полезные ископаемые мамонской песчано-каолиновой толщи / А. Д. Савко, С. В. Мануковский, Л. Т. Шевырев // Тр. науч.-исслед. ин-та геологии Воронеж. ун-та. - Вып.53. - Воронеж, 2008. - 112 с.

13. Ненахов, В. М. Интегральная модель россыпеобразования на территории Воронежской антеклизы / В. М. Ненахов, Г. С. Золотарева // Литол. и полезн. ископ. -2012 . - № 1. C. 26-40.

14. Савко, А. Д. Ассоциации минералов-индикаторов алмазоносности в осадочном чехле Воронежской антеклизы / А. Д. Савко, Л. Т. Шевырев, В. В. Ильяш // В сб. Проблемы алмазной геологии и некоторые пути их решения. - АК АЛРОСА (ЗАО). Воронеж, 2001. - С. 423-433.

15. Черешинский, А. В. Акцессорные минералы базальных горизонтов Воронежской антеклизы (в связи с вопросами алмазоносности) / А. В. Черешинский, А. Д. Савко // Тр. науч.-исслед. ин-та геологии Воронеж. ун-та. - Вып.48. Воронеж. - 2007. - 120 c.

Voronezh State University

Nikitin E. Yu. - Master of Geology

E-mail: nikitinevgeniyurievich@yandex.ru

Tel: 89290100853 